\title{
Superblok Bisnis Dengan Pendekatan Green Metropolis Di JaKarta Utara, Penekanan Pada Area Bisnis Dan Komersial
}

\author{
Galih Ajie Nugraha, B.Heru Santosa, Amin Sumadyo \\ Program Studi Arsitektur \\ Fakultas Teknik \\ Universitas Sebelas Maret Surakarta \\ Email : galih.graha@yahoo.com
}

\begin{abstract}
Business Superblock in North Jakarta motivated by the potential and high economic attractiveness of Jakarta but not matched with good urban planning so that Jakarta is not ready to accept urbanization and has residential and transportation issues. The objective of this scheme is to get the design of superblock area is able to accommodate business and commercial activities, supported by residential facilities and access to public transportation. The method used is a method of planning and architectural design through an approach that is taken from the book of David Owen: Green Metropolis : Why Living Smaller, Living Closer, and Driving Less are the keys to sustainability. Design issues to be resolved are: the selection and processing footprint suitable for the needs of a superblock, and can support both business and commercial activity as main activity, as well as residential and recreational activities as secondary activities. The results are a design of superblock area is able to accommodate business activities and commercial (work), residential, and recreation with the support of public transportation access with the Green Metropolis approach.
\end{abstract}

Keywords: Business Superblock, Green Metropolis, Business and Commercial, Mix-Used.

\section{PENDAHULUAN}

DKI Jakarta merupakan kota metropolitan yang memiliki magnet untuk menjadi daerah tujuan kedatangan karena Jakarta memiliki fungsi pusat pemerintahan dan pusat bisnis tanah air sehingga menjadi kota yang sangat prospektif. Namun dibalik potensinya, Jakarta juga mempunyai segudang problematika seperti angka urbanisasi yang tinggi.

Semakin tingginya populasi manusia di suatu daerah maka kebutuhan akan tempat tinggal pun semakin meningkat. Banyak lahan terbuka hijau terkonversi menjadi rumahrumah penduduk dan jalan raya. Padahal idealnya suatu kota harus memilik sekurangkurangnya 30\% lahan terbuka hijau dan area peresapan air hujan. Terjadi perubahan drastis guna lahan DKI Jakarta antara tahun 1970 dan 2000 (lihat Gambar 1), dimana pada tahun 1970 lahan terbangun terkonsentrasi di Jakarta Pusat, namun saat ini wilayah Jakarta lainnya (utara, timur, selatan dan barat) dipenuhi oleh lahan terbangun. Idealisme masyarakat Jakarta sangatlah tinggi, namun apabila hal ini dibiarkan terus menerus, Jakarta akan menjadi kota yang stress, tidak memiliki lahan terbuka hijau dan sistem transportasi yang jelas untuk meningkatkan taraf kualitas hidup masyarakatnya (Badan Pusat Statistik Provinsi DKI Jakarta).

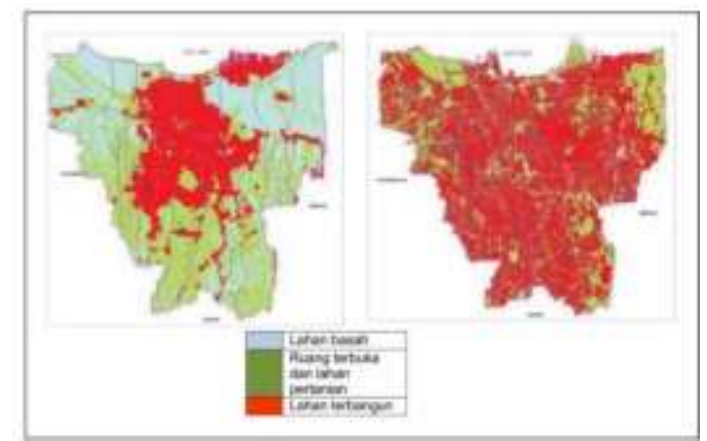

Gambar 1. Peta Perubahan Guna Lahan DKI Jakarta Tahun 1970 dan 2000

Sumber : BPS Provinsi DKI Jakarta

Dari fenomena tersebut, sehingga diperlukan sebuah pemecahan masalah urban dengan membangun kompleks superblok. Superblok merupakan suatu kawasan di 
konteks urban yang dirancang secara terpadu dan terintegrasi (integrated developement), berdensitas cukup tinggi dalam konsep tata guna lahan yang bersifat campuran (mixed- use).

Superblok dapat menjadi idiom baru dalam bisnis properti di Indonesia karena digadang-gadang dapat mengubah pola hidup masyarakat urban yang selama ini tinggal berjauhan dengan tempat kerja semisal masyarakat yang tinggal di wilayah suburban, menjadi one stop living. Dalam satu lokasi, masyarakat bisa tinggal, bekerja, dan berekreasi (Tardiyana, 2010).

Pendekatan yang diambil adalah konsep Green Metropolis dari buku karya David Owen (2009) Green Metropolis: Why Living Smaller, Living Closer, and Driving Less are the keys to sustainability. David Owen menekankan tentang konsep "hidup lebih dekat" sehingga integrasi antara wadah bertempat tinggal, bekerja dan berekreasi hubungannya semakin erat dan merubah pola hidup menjadi vertikalisme. Konsep ini sangat diperlukan bagi kota-kota besar yang sudah padat penduduknya karena dari sini dapat mengurangi intensitas frekuensi transportasi. Konsep ini juga menekankan sisi ekologis hubungan antara manusia, bangunan dan alam.

\section{METODE}

Metode yang akan dilakukan guna mendapatkan data yang akan digunakan untuk proses dasar penyusunan sebuah konsep. Dalam hal ini terdapat beberapa metode yang dilakukan guna tujuan tersebut, terdiri dari metode pengumpulan data primer dan sekunder.

1. Metode Pengumpulan Data Primer

a. Melalui survey terhadap superblok yang telah ada, survey yang dilakukan guna mendapatkan data pendukung berupa data statistik fakta-fakta tentang perkembangan superblok yang terdapat di Jakarta dan kota lain yang ada di Indonesia.

b. Kondisi tapak, data sosial dan lingkungan didapat dengan observasi secara langsung dan dokumentasi serta wawancara secara langsung kepada masyarakat setempat dan instansional terkait.
2. Metode Pengumpulan Data Sekunder

Studi Literatur :

a. Preseden superblok didapat dari referensi buku/e-book yang berkaitan dan representatif dan referensi kasus konsep perancangan yang sudah ada

b. Konsep green metropolis didapat langsung dari buku karya David Owen (2009) Green Metropolis: Why Living Smaller, Living Closer, and Driving Less are the keys to sustainability

c. Konsep green building didapat dari mata kuliah tentang arsitektur hijau serta beberapa buku referensi.

d. Rencana Struktur Tata Ruang Wilayah DKI Jakarta didapat melalui data instansional pemprov dan pemkot serta melalui situs dan artikel terkait.

3. Metode Mengolah Data

Terdapat beberapa langkah dalam mengolah data yang didapat baik data primer maupun data sekunder, di antaranya

a. Penyortiran Data

Menyortir data yang diperlukan, penyortiran dilakukan sesuai dengan aspek penekanan superblok yang ingin dirancang.

b. Korelasi Data

Mengkorelasikan/menghubungkan antara data yang satu dengan data yang lainnya, data primer dan data sekunder.

c. Pemaparan Data Memaparkan hasil data yang didapat dan disajikan ke dalam beberapa bentuk, di antaranya deskripsi data, gambar, dokumentasi, tabel dan grafik.

d. Analisis Data

1) Analisa data yang didapat di lapangan (data primer) dengan data yang didapat melalui referensi (data sekunder)

2) Menganalisa data, guna mendapatkan aspek-aspek yang sesuai dengan dasar-dasar konsep green metropolis

3) Membagi tiap-tiap data yang didapat kedalam pokok-pokok pembahasan dan dijadikan sebagai data pendukung 
4) Mencari benang merah antara superblok dengan konsep green metropolis berdasarkan data yang sudah didapat.

e. Penarikan Kesimpulan

\section{ANALISIS}

\subsection{Analisis Pengguna dan Kegiatan}

Analisis pertama yang dilakukan adalah mengetahui siapa saja pengguna yang akan menggunakan superblock beserta kegiatannya

a. Tujuan

Mengetahui kegiatan setiap pengguna yang akan menjadi pengguna superblok.

b. Dasar pertimbangan

Objek rancangan dapat menampung kegiatan seluruh pengguna yang direncanakan

c. Proses analisis

Penentuan pengguna nanti akan digunakan untuk menentukan kebutuhan ruang.

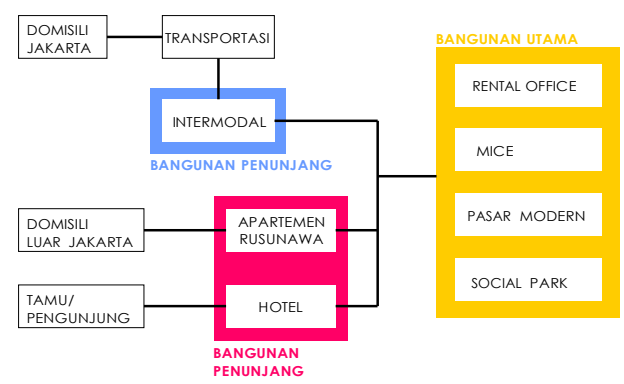

Gambar 2. Model Konsep Kegiatan Makro

Ada beberapa pengguna yang digolongkan menjadi pengguna superblok ini antara lain (lihat Gambar 2) :

1. Pengguna yang berdomisili di Jakarta Pengguna yang berdomisili asli Jakarta akan diarahkan menggunakan transportasi umum seperti commuterline dan busway sehingga superblok harus mampu menyediakan intermodal sebagai sarana transit dan naik turun kendaraan umum tersebut. Superblok ini akan merubah perilaku masyarakat Jakarta yang tadinya terbiasa menggunakan kendaraan pribadi menjadi menggunakan kendaraan umum sebagai upaya mengurangi polusi kendaraan dalam skala makro.

2. Pengguna yang berdomisili di luar Jakarta

Pengguna yang berdomisili di luar Jakarta akan diberikan fasilitas apartemen sewa ataupun rumah susun sewa. Hal ini sangat penting mengingat kapasitas superblok.

3.Tamu/pengunjung

Tamu dan pengunjung sifatnya merupakan pengguna dengan masa huni paling singkat sekitar hanya beberapa hari bahkan beberapa jam, dan bukan termasuk penghuni superblok. Tamu yang butuh bermalam dan menginap akan disediakan hotel.

\subsection{Analisis Peruangan}

Mencari kebutuhan peruangan dengan mempertimbangkan kegiatan yang ada didalam superblok.

Tabel 1.Kebutuhan Ruang Makro

\begin{tabular}{|l|l|}
\hline KEGIATAN & PERUANGAN \\
\hline Bisnis & Gedung Kantor Sewa \\
\hline Komersial & Gedung Shopping Center \\
\hline Pertemuan & Gedung MICE \\
\hline Hunian & $\begin{array}{l}\text { Apartemen (middle-high) } \\
\text { Rumah Susun (middle- } \\
\text { low) } \\
\text { Hotel (tamu/pengunjung) }\end{array}$ \\
\hline $\begin{array}{l}\text { Rekreasi dan } \\
\text { Olahraga }\end{array}$ & Green-Social Park \\
\hline Parkir & Gedung Parkir Terpadu \\
\hline $\begin{array}{l}\text { Transportasi } \\
\text { Umum }\end{array}$ & $\begin{array}{l}\text { Intermodal } \text { (Commuter } \\
\text { Line dan Busway Transit) }\end{array}$ \\
\hline $\begin{array}{l}\text { Pusat } \\
\text { Kepengelolaan }\end{array}$ & Central Office \\
\hline
\end{tabular}

Pada Tabel 1. terlihat kebutuhan peruangan yang dibutuhkan dalam pemenuhan wadah keseluruhan kegiatan di dalam area superblok.

\subsection{Analisis Lokasi}

Menentukan lokasi yang strategis dan memilih tapak dengan kondisi yang mendukung keberadaan superblok ini sangat menentukan prospek bangunan tersebut. 
a. Tujuan

Mendapatkan lokasi yang sesuai dengan kebutuhan superblok

b. Dasar pertimbangan: Posisi tapak strategis untuk ekspose tampilan fisik bangunan, luasan tapak dapat menampung seluruh kebutuhan ruang yang direncanakan.

c. Proses analisis Dengan cara mengetahui luasan tapak, batas tapak dan kondisi lingkungan.

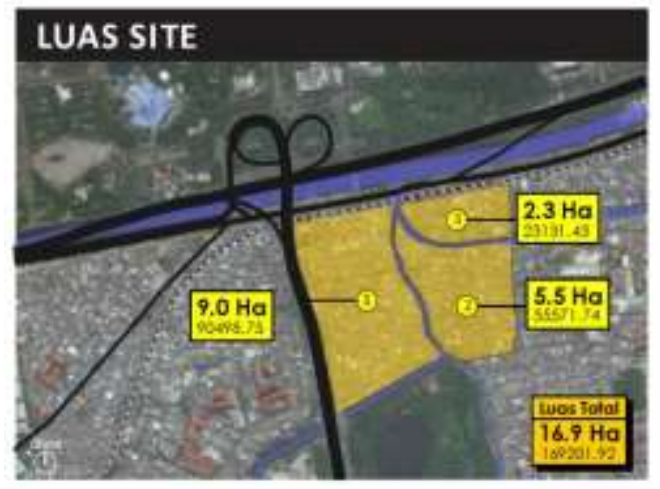

Gambar 3. Luas Tapak

Luas keseluruhan lahan yang akan diolah menjadi superblok adalah 169201.92 meter persegi atau 16.9 hektar dengan rincian (lihat Gambar 3) :

1. Lahan bagian barat : $90498.75 \mathrm{~m}^{2}$ (9.0 hektare)

2. Lahan bagian timur laut : $55571.74 \mathrm{~m}^{2}$ (5.5 hektare)

3. Lahan bagian tenggara : $23131.43 \mathrm{~m}^{2}$ (2.3 hektare)

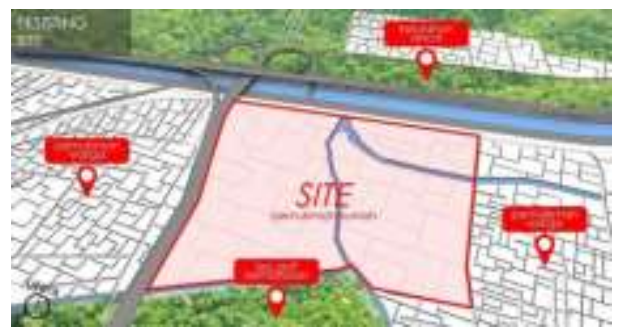

Gambar 4. Batas-batas tapak

Batas-batas tapak antara lain (lihat Gambar 4):

1. Arah utara tapak terdapat jalur kereta api yang biasa dilalui kereta jarak jauh maupun kereta commuter line. Jalur ini menghubungkan Stasiun Tanjung Priok - Stasiun Pasar Senen atau Stasiun Tanjung Priok - Stasiun Jakarta Kota. Di utaranya lagi adalah Jl.RE Martadinata dan J1. Tol Pelabuhan.

2. Arah timur, bersebelahan langsung dengan tapak merupakan jalan lingkungan yaitu Jl.Muara Bahari Raya. Tersebar dengan luas perumahan warga dan terdapat Pondok Pesantren Al-Mutaqqien.

3. Arah selatan tapak adalah Jl.Pademangan Timur 15 dan Jl. Muara Bahari Barat Raya. Jalan ini merupakan jalan lingkungan. Di sebelah selatannya lagi adalah Padang Golf Kemayoran, namun untuk akses masuk ke dalam lapangan golf ini tidak melalui titik ini.

4. Arah barat site adalah jalan arteri yaitu Jl. Benyamin Suaeb dan terdapat Pintu Gerbang Tol Pelabuhan (Jakarta Inner Ring Road).

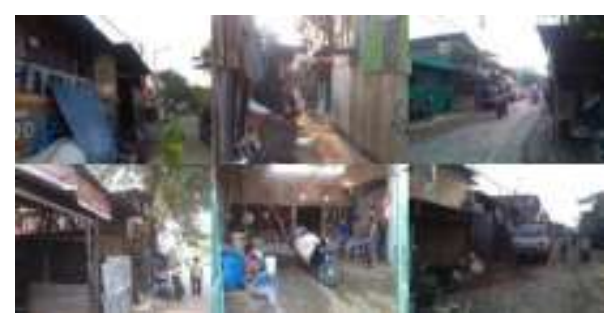

Gambar 5. Kondisi Lingkungan

Kondisi lingkungan di Pademangan Timur khususnya tapak yang akan diolah didominasi oleh pemukiman kumuh dan liar (lihat Gambar 5), banyak rumah semi permanen dan bangunan yang melanggar garis sempadan bangunan maupun sungai. Rumah-rumah yang berdiri di atas tapak merupakan rumah- rumah yang tidak memiliki IMB (Izin Membangan Bangunan) dari pemertintah yang sah, karena memang tanah ini adalah tanah milik pemerintah daerah. 


\subsection{Analisis Pemintakatan (Zoning)}

Pemintakatan berdasarkan sifat kegiatan dan keadaan dalam tapak dilakukan sebagai acuan dalam penataan peruangan

1. Tujuan

Menentukan mintakat (zoning) berdasarkan sifat kegiatan dan keadaan pada tapak

2. Dasar pertimbangan

Analisis peruangan dan analisis pengolahan tapak

3. Proses analisis

Persyaratan ruang, berdasarkan kelompok kegiatan dan analisis pengolahan tapak

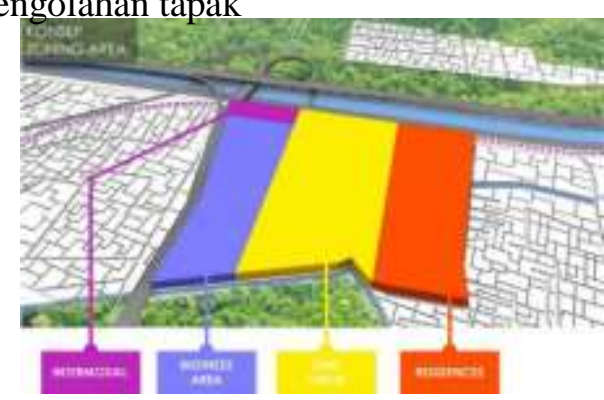

Gambar 6. Analisa Pemintakatan

Pengorganisasian ruang (gedung) akan dibagi menjadi tiga kategori berdasarkan tingkat privasinya (lihat Gambar 6), antara lain :

\section{a. Publik}

Area publik adalah area dengan privasi yang rendah karena sifat area ini yang dipergunakan untuk fasilitas umum seperti rental office, pasar modern, dan MICE (meeting, intencive, convenience, dan exhibition). Area ini akan digunakan oleh pengguna superblok setiap harinya dengan intensitas pengunjung yang tinggi. Area publik dipilih di area dengan orientasi yang tinggi, dekat dengan jalan tol dan jalan arteri yang mampu menjadi daya tarik superblok.

b. Semipublik

Area sempublik adalah area yang terbatas penggunaannya oleh pengguna superblok. Ruang semipublik akan digunakan sebagai area taman sosial sebagai fasilitas tambahan pengguna superblok.

\section{c. Privat}

Area privat adalah area yang sangat terbatas dengan tingkat privasi tertinggi. Di area ini, akan dibangun high rise residence seperti hotel, apartemen dan rumah susun sewa.

\subsection{Analisis Tata Massa dan Hubungan Ruang}

Dalam menganalisa pola tata massa, penulis mempertimbangkan kembali analisis pemintakatan yang telah dilakukan sebelumnnya.

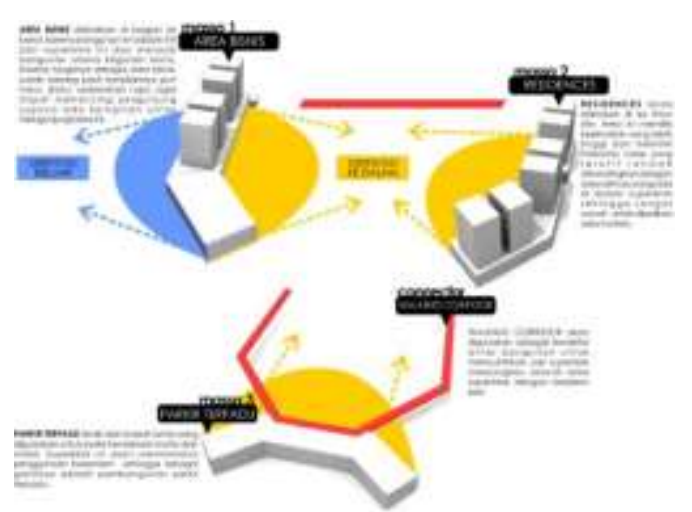

Gambar 7. Pola Tata Massa

Pertimbangan dalam menata massa gedung di dalam superblok antara lain

a. Meminimalisir jumlah dan luasan massa bangunan untuk memaksimalkan green space

b. Mengatur jarak antar massa untuk memaksimalkan potensi alami : udara, matahari

c. Mengatur ketinggian bangunan agar potensi alami dapat dimanfaatkna di semua massa bangunan

d. Orientasi massa bangunan mampu merespon kondisi iklim mikro dan makro di sekitar bangunan 


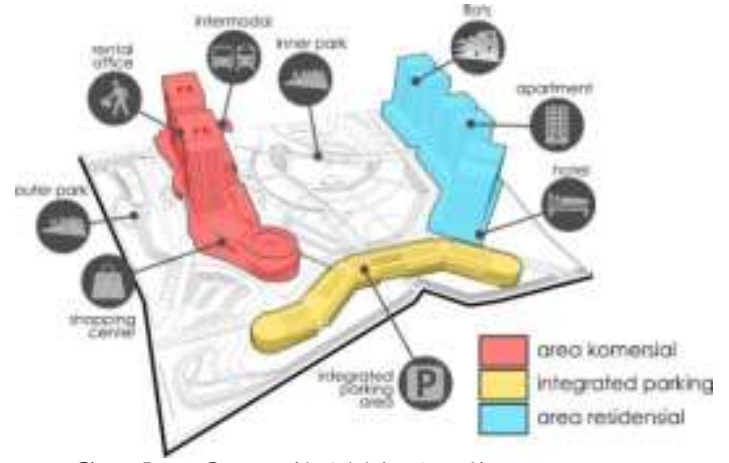

Gambar 8. Hasil Akhir Analisa Tata Massa

Gambar di atas menjelaskan konsep yang digunakan dalam penataan massa superblok, bangunan berwarna merah adalah area bisnis dan komersial, bangunan berwarna biru adalah area residensial, dan area berwarna kuning adalah parkir terpadu yang menghubungkan area bisnis dan komersial dengan area hunian atau residensial.

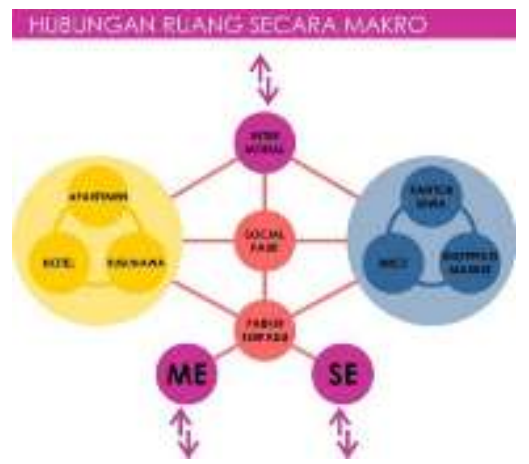

Gambar 9. Analisa Hubungan Ruang secara Makro

Dalam proses penataan hubungan ruang (dalam hal ini fungsi gedung) dibagi menjadi tiga kategori yaitu (lihat Gambar 9):

1. Primary building yang menjadi ujung tombak dalam kegiatan bisnis dengan bangunan rental office dan MICE didukung sarana hiburan mall, pasar modern, dan social park

\section{Secondary building (bangunan} residential)

3. Bangunan fasilitas transportasi yaitu intermodal dan parkir terpadu
Setiap bangunan akan dihubungkan dengan koridor/konektor agar konsep fungsi mix-used yang terintegrasi dapat tercapai. Ada empat koridor yang menghubungkan empat masssa bangunan utama di dalam superblok (lihat Gambar 10).

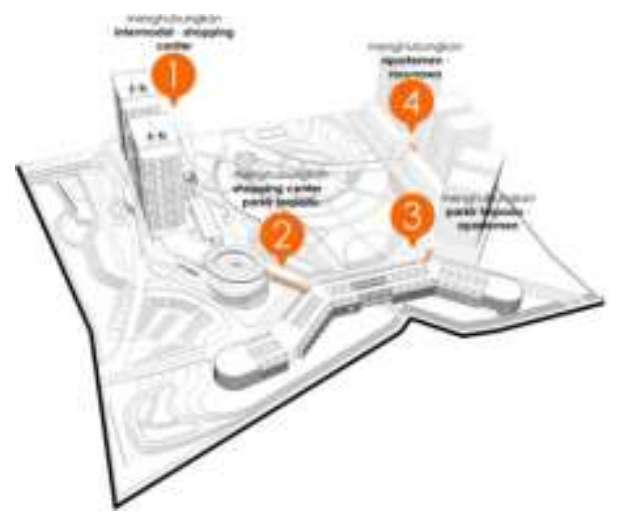

Gambar 10. Konektivitas antar Gedung

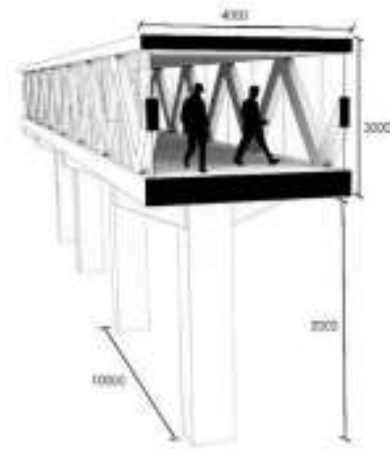

Gambar 11. Model Konektor antar Fungsi Gedung

\subsection{Analisis Bentuk dan Tampilan Bangunan}

Pengolahan dinding dalam komplek superblok menjadi hal yang penting untuk mendukung pengaplikasian teori green metropolis dimana bangunan sebagai objek harus mampu mengurangi ketergantungan terhadap energi tak terbarukan, sehingga pengaplikasian penghawaan dan pencahayaan alami mampu menjadi alternatif untuk mengurangi penggunaan energi yang berlebihan. 


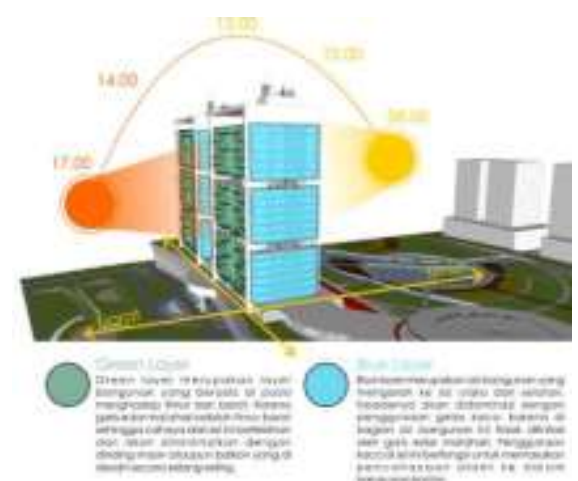

Gambar 12. Konsep Tampilan Gedung Kantor Sewa

Sisi dinding pada bangunan komersial akan dibedakan menjadi dua jenis yaitu green layer dan blue layer (lihat Gambar 12). Green layer merupakan sisi yang berada di posisi menghadap timur dan barat, karena garis edar matahari adalah dari timur ke barat, sehingga cahaya yang masuk dari sisi ini memiliki intensitas yang tinggi dan akan diminimalkan dengan penggunaan dinding masif

dan green balcony yang didesain berselingan.

Sedangkan blue layer merupakan sisi bangunan yang mengarah ke utara- selatan, fasadnya akan didominasi dengan penggunaan dinding kaca karena di area ini tidak dilalui garis edar matahari. Penggunaan kaca akan ditambah dengan sistem dinding tirai yang berada pada ruang-ruang rental office, dinding tirai ini merupakan dinding fleksibel yang dapat digunakan untuk mengatur besar kecilnya cahaya yang dibutuhkan untuk masuk ke dalam ruangan.

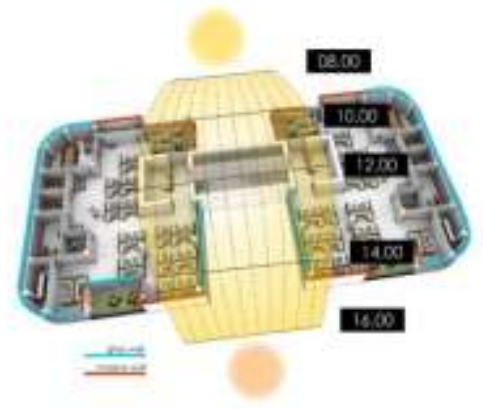

Gambar 13. Konsep Fasad sebagai Pencahayaan Alami

\subsection{Analisis Lansekap}

Skenario pengaturan kontur pada superblock juga menjadi poin yang harus dipertimbangkan secara matang. Walaupun sungai yang membelah tapak tidak menimbulkan dampak banjir selama 10 tahun terakhir, namun dimasa yang akan datang sebagai pencegahan terhadap potensi banjir, maka pengaturan kontur pada bangunan mutlak diperlukan, area yang diduduki secara langsung oleh bangunan gedung akan dinaikan untuk mencegah air yang disebabkan oleh luapan banjir (lihat Gambar 14).

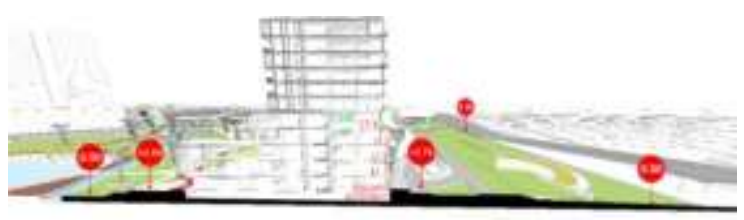

Gambar 14. Konsep Pengaturan Ketinggian Kontur

Elemen lansekap dalam superblok ini akan dibagi menjadi dua bagian yaitu lansekap bagain depan dan tengah. Taman di bagian depan tidak sebesar taman yang berada di bagian tengah superblok karena taman depan hanya difungsikan sebagai garis sempadan bangunan dan elemen pendukung fasade bangunan. Sedangkan taman di bagian tengah adalah taman yang mengakomodir kegiatan sosial di dalam superblok.

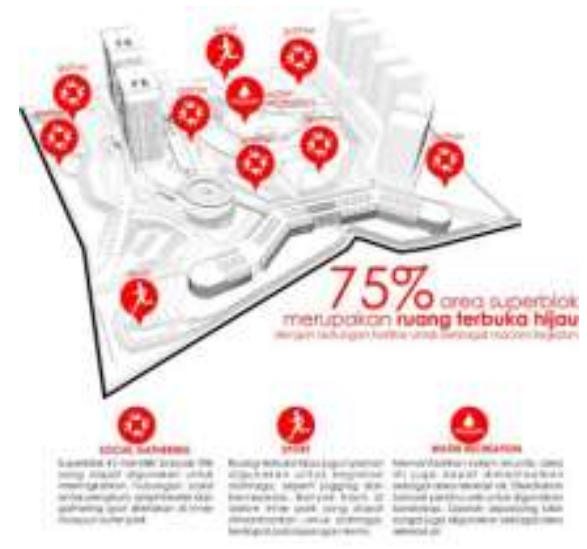

Gambar 15. Konsep Lansekap sebagai Fasilitas Kegiatan Superblok 


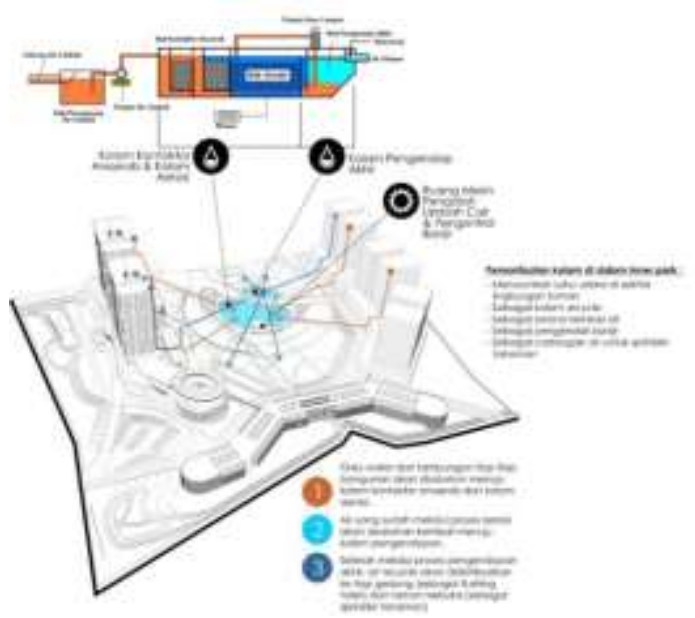

Gambar 16. Proses Pengolahan Grey Water dalam Superblok

Air hujan dan grey water (air bekas wastafel dan air bekas cucian) akan disalurkan menuju kolam penjernihan yang berada di area taman utama. Jadi selain menjadi pengendali banjir, kolam ini juga berfungsi sebagai kolam penjernihan. Setelah proses penjernihan selesai dengan bantuan tanaman air untuk membunuh bakteri yang terkandung di dalam grey water, air olahan ini diangkat menuju water tank untuk kemudian selanjutnya di distribusikan ke tiap-tiap unit lavatory untuk flushing toilet ataupun untuk air sprinkler tanaman (lihat Gambar 16).

\section{KESIMPULAN (KONSEP DESAIN)}

Dari hasil analisa serta hasil korelasi dari beberapa data di atas, maka diperoleh hasil berupa desain Superblok Bisnis dengan

Pendekatan Green Metropolis di Jakarta Utara sebagai berikut.

Nama Objek: Superblok Bisnis Jakarta Utara

Lokasi : Jl.Benyamin Suaeb,

Pademangan Timur, Jakarta

Utara

Luas Lahan : $169201 \mathrm{~m}^{2}$ (16.9 Ha)

Kegiatan : Bisnis, Komersial,

Rekreasi, dan Hunian

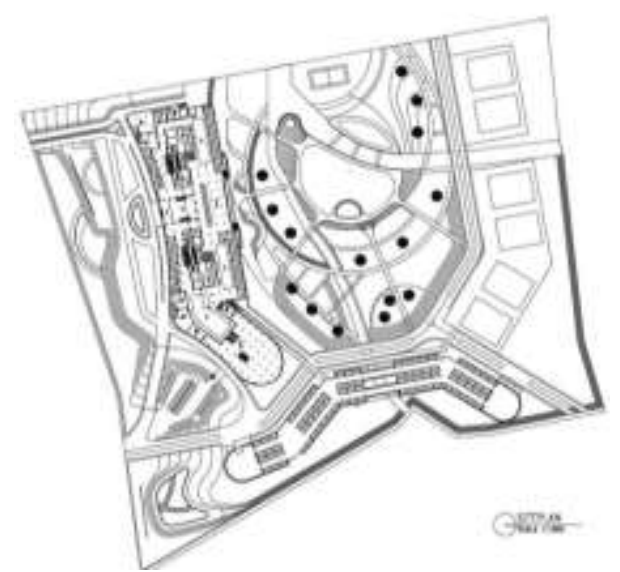

Gambar 17. Siteplan

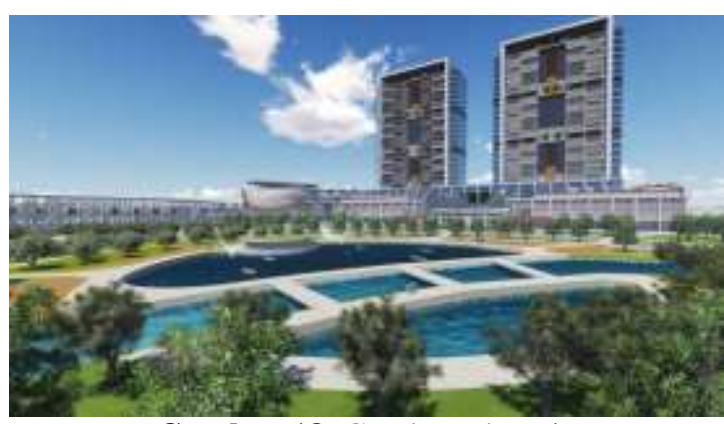

Gambar 18. Gambar Eksterior

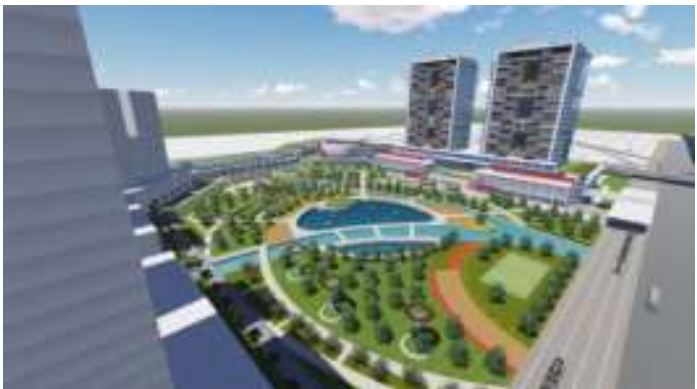

Gambar 19. Gambar Aerial View

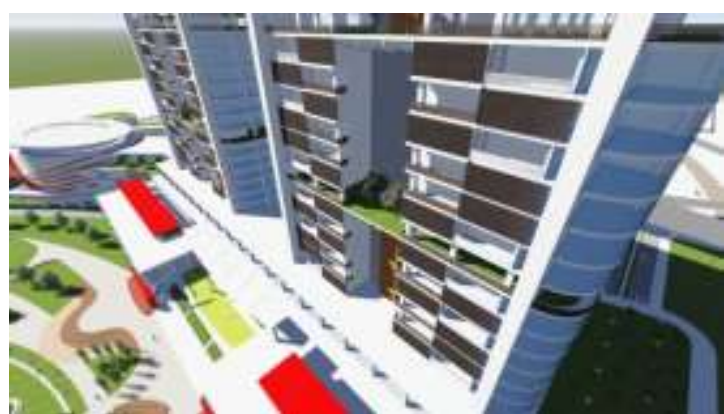

Gambar 20. Gambar Eksterior 


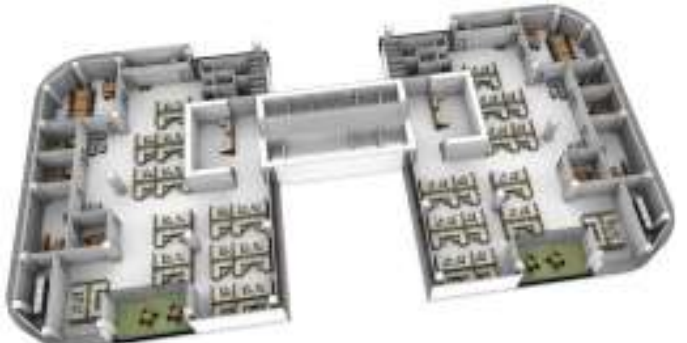

Gambar 21. Gambar Interior

\section{REFERENSI}

Badan Pusat Statistik Provinsi DKI Jakarta.

Owen David. Green Metropolis. Why Living

Smaller, Living Closer, and Driving

Less are the keys to sustainability. 2009.

Tardiyana, Achmad. Skala Plus On

Contemporary Design. Ekspresi dan

Gaya Hidup Metropolis.201 
